УДК 316.422 .44

$10.17213 / 2075-2067-2021-4-73-92$

\title{
ЦИФРОВИЗАЦИЯ В МАЛОМ ГОРОДЕ: РЕЛИГИОЗНОСТЬ КАК ФАКТОР ВЛИЯНИЯ?
}

\author{
(C) 2021 г. И. П. Рязанцев*, М. А. Подлесная **, \\ В. Г. Писаревский
}

\section{"Православный Свято-Тихоновский гуманитарный университет, г. Москва, Россия *"Институт социологии Федерального научно-исследовательского социологического центра РАН, г. Москва, Россия *** Московский государственный университет имени М. В. Ломоносова, г. Москва, Россия}

Цель исследования. На сегодняшний день Россия входит в десятку стран-лидеров по уровню развития ичирровизации и ичифровой экономики (The digital economy and society index (DESI)). На уровне Правительства РФ разработана специальная программа «Цифровая экономика Российской Федерации», в рамках которой до 2030 года обозначены приоритетные ицифровые технологии (беспроводная высокоскоростная связь, большие данные, искусственный интеллект, Интернет вещей, виртуальная и дополненная реальности), а также ключевые задачи для внедрения данных технологий (развитие интернет-инфраструктуры в регионах $Р \Phi$, создание регулятивной среды ииифровой экономики, создание образовательной среды для подготовки кадров циифровой экономики, государственно-частное партнерство в развитии иифровых платформ). Реализация данной правительственной программы сегодня активно осуществляется в федеральных и региональных иентрах, в крупных и мальх городах. Цель статьи рассмотрение влияния такого фактора, как православная религиозность, на прочесс ицифровизаиии.

Методологическая база исследования. Территорией исследования был выбран Кирилловский район Вологодской области, который отличает наличие древних памятников православной культуры и зодчества, особый исторический и культурный контекст, связанный с территориями так называемого «Русского Севера». Кроме того, данный регион интересен тем, что это мальй город и периферийная территория, в равной степени удаленная от таких крупных агломерационных иентров, как Вологда и Череповец. Развитие соииального процесса цุифровизации здесь может быть обусловлено православной религиозностью и специификой малого города.

В 2019 году был осуществлен второй замер сочиильно-экономических, демографических, религиозных условий жизни населения Кирилловского района Вологодской области (первый замер был произведен в 2009 году). Были заданы вопросы об отношении населения к ичифровизачии, качестве технического оснащения региона с точки зрения мобильной и интернет-связи, пользовательских возможностях населения и т.д.

Результаты исследования. В результате было обнаружено отсутствие связи между православной религиозностью населения и его отношением к процессу ичифровизации, готовностью включаться в него. Было выявлено, что при $40 \%$ тех, кто не включен в прочесс цифровизации в регионе, подавляющее большинство (76\%) выразили свое позитивное отношение к происходящим изменениям. 
Перспективы исследования. Продолжение начатого мониторинга, замер динамики циифровизачии в малом городе и изменений, происходящих в пользовательской среде и в оиенке процессов цฺифровизации в регионе населением.

Ключевые слова: цุифровизация; иифровая трансформащия; иүифровая экономика; православная религиозность; мальий город; Русский Север.

\title{
DIGITALIZATION IN A SMALL TOWN: RELIGIOSITY AS A FACTOR OF INFLUENCE?
}

\author{
(C) 2021 I. P. Ryazantsev", M. A. Podlesnaya**, \\ V. G. Pisarevsky*, V. I. Ryazantsev ${ }^{* * *}$ \\ "St. Tikhon's Orthodox University, Moscow, Russia \\ **Institute of Socilogy of the Federal Research Sociological Center \\ of the Russian Academy of Sciences, Moscow, Russia \\ ***Lomonosov Moscow State University, Moscow, Russia
}

The purpose of the research. Currently Russia is among the top ten countries in terms of digitalization and digital economy development. The Government of Russian Federation has developed a special program "Digital economy of the Russian Federation», within the priority of digital technologies (wireless high-speed communication, big data, artificial intelligence, Internet of things, virtual and augmented reality) are identified until 2030, as well as key tasks for implementing these technologies (development of Internet infrastructure in the regions of the Russian Federation, creation of a regulatory environment for the digital economy, creating an educational environment for training digital economy personnel, public-private partnership in the development of digital platforms). The implementation of this Government program is currently actively carried out in both federal and regional centers, both in large and small cities, both in agglomerations and in peripheral territories. The purpose of the research - to consider the influence of such a factor as Orthodox religiosity on the process of digitalization.

The methodological framework of the research. The research area was chosen as the Kirillovsky district of the Vologda region, which is distinguished by the presence of ancient monuments of Orthodox culture and architecture, a special historical and cultural context associated with the territories of the so-called «Russian North». In addition, this region is interesting because it is a small city and a peripheral territory, equally remote from such large agglomeration centers as Vologda and Cherepovets. The development of the social process of digitalization here may be due to both Orthodox religiosity and the specifics of a small city.

In 2019, the second measurement of socio-economic, demographic, and religious conditions of the population of Kirillov district, Vologda region (the first measurement was made in 2009) was carried out. Questions were asked about the attitude of the population to digitalization, the quality of technical equipment in the region in terms of mobile and Internet communication, user capabilities of the population, etc.

The results of the study. As a result, it was found that there is no connection between the Orthodox religiosity of the population and their attitude to the process of digitalization, their readiness to be included in it. It was found that with $40 \%$ of those who are not included in the digitalization process in the region, the vast majority (76\%) expressed their positive attitude to the changes taking place.

The perspective of the research. This is a continuation of the monitoring begun, measuring 
the dynamics of digitalization in a small city and changes taking place in the user environment and in assessing the digitalization processes in the region by the population.

Key words: digitalization; digital transformation; digital economy; Orthodox religiosity; small city; Russian North.

Введение. Проблемная область, которую мы хотели бы обозначить в данной статье, связана преимущественно с тем, что развитие российской экономики, которая определенными авторами рассматривается как структурно отстающая [31, 116], в том числе зависит от культурной специфики и в частности детерминирована ее религиозным контекстом $[22,25,26]$. Можем ли мы говорить в этой связи о том, что конфессиональный аспект существенно влияет на отношение населения к новым технологиям и инновациям и в действительности тормозит социальный процесс цифровизации в России? Попытаться дать ответ на этот вопрос мы хотели бы на примере анализа эмпирических данных, полученных в результате проведенного нами исследования в Кириллове и Кирилловском районе Вологодской области в 2009 и 2019 годах.

Надо отметить, что Кирилловский район Вологодской области с точки зрения поставленной проблемы весьма интересен, так как насчитывает 12 памятников культового и 25 гражданского зодчества под государственной охраной, среди которых Кирилло-Белозерский, Ферапонтов монастыри, Нило-Сорская пустынь, музей фресок Дионисия, национальный парк «Русский Север» и др. Кирилловский район, как и Вологодская область в целом, причисляется к территориям так называемого «Русского Севера», о котором различными исследователями говорится, как о территориях с населением, где наиболее ярко выразилась «русскость» и типичность «великоросса» $[8$, с. 176-186]. «Современные исследователи пишут не только о "заслуге Русского Севера в развитии культуры и образования" [Булатов 1999, с. 258], но также и о "метафизике Севера", о его “сакральной географии”, которая якобы и выделяет его в особую культурную реальность, и позволяет говорить о нем, как о едином культурном пространстве [Теребихин 2004] » [24, с. 142].
Вместе с тем в настоящее время данный район, как и Вологодская область в целом, претерпевает ряд демографических и социально-экономических трудностей: это депопуляция и постарение населения, сокращение жителей брачного возраста, отток молодежи в другие, более крупные города, снижение числа мигрантов, приезжающих в регион [6]. В условиях реализуемой Стратегии пространственного развития Российской Федерации (Федеральный закон от 28 июня 2014 г. №172-Ф3 «О стратегическом планировании в Российской Федерации») подобная ситуация района усугубляется еще и тем, что будучи территориально отдаленным от центральных городов (от Вологды - 129 км, от Череповца - 100 км), Кирилловский район не вписывается в систему агломераций и отнесен к регионам со средним уровнем социокультурной модернизации [5].

В контексте происходящего цивилизационного сжатия наблюдается не только постарение населения, но и социальная инерция населения Русского Севера в целом, говорится о «колее» как жизненном сценарии прежде всего взрослого населения $[11,20]$.

В нашем исследовании мы рассматриваем, с одной стороны, регион с культурным и религиозным своеобразием, с другой наиболее типичный с точки зрения своего территориального развития. Кирилловский район Вологодской области интересен еще и тем, что, будучи хранителем памятников древней архитектуры и зодчества, район и его жители вынуждены жить в соответствии с имеющимся наследием, не просто сохраняя данную культуру, но и будучи ее частью. Поэтому здесь, как нигде в другом месте, может наблюдаться конфликт традиции и новых цифровых технологий, невосприимчивость к инновациям или, напротив, собственное прочтение и отношение к происходящим изменениям. 
Методы и материалы исследования. Под малым городом в своем исследовании мы понимаем такое поселение, такую территорию, которая устанавливается в качестве городской в соответствии с правовым статусом «город» и численностью населения до 50 тыс. человек, делая при этом акцент на эндогенных и экзогенных связях города [18], организованных, прежде всего, его жителями, которые трудятся и вступают в трудовые отношения, создают семьи и организуют семейно-бытовую деятельность, проявляют свою общественно-политическую активность, являются производителями и потребителями материальных и духовных благ, заботятся о своем здоровье и здоровье своих детей и т.д. [16]. По сути, «это место - локус социального пространства, где накапливается, развивается и реализуется человеческий и социальный потенциал большей или меньшей по размеру и сложности городской общности; это - ресурсные центры и инфраструктурные узлы для освоения и развития окружающей сельской местности, природной территории» [16, с. 212].

В исследовании был задействован ряд урбанистических теорий, в частности, связанных с концепцией территориального и цивилизационного «сжатия», которая в литературе зарубежных авторов представлена, начиная с 70-х гг. XX века. Это, прежде всего, теория городской эволюции Ван ден Берга [37], концепция «сжатия» в результате глобализации и глобальной реструктуризации, представленная в работах Д. Харви [28], С. Сассен [33], А. Скотта и М. Сторпера [34] и др., концепция регионального фактора «сжатия» городов $[32,27]$. Так как данная работа носит межотраслевой характер, то были также привлечены теории коммуникации и цифрового общества, о которых подробнее изложим отдельно, и положения из области социологии религии, касающиеся измерения религиозности населения и уровня воцерковленности (о чем подробнее в соответствующей части).

Основным методом нашего исследования (помимо включенного наблюдения и вторичного анализа данных) стал анкетный опрос населения. Социологические опросы проводились информационно-аналитическим центром факультета социальных наук Православного Свято-Тихоновского гуманитар- ного университета с помощью анкеты в 2009 и 2019 годах. Исследование повторное, проводилось по единым программе и инструментарию с целью изучения происходящих изменений городской среды в оценке жителей города Кириллова и его района.

Выборка многоступенчатая и формировалась исходя из представлений о том, что сам Кириллов состоит из восьми микрорайонов, а Кирилловский район - из девяти сельских советов, к которым относятся в общей сложности 469 сел и деревень (в том числе нежилые). Отбор улиц, домов, квартир осуществлялся с помощью генератора случайных чисел, мы действовали методами невероятностной выборки в 2009 году, в 2019 году шли по уже отобранным в 2009 году улицам, домам. Квартиры и жильцы, опрошенные в 2009 году, были чаще всего недоступны, поэтому использовался шаг.

В 2009 году общее число жителей Кириллова и Кирилловского района составляло 18627 человек, из них городского населения 7933 человек, сельского — 9866 человек. К 2019 году численность населения Кириллова и Кирилловского района заметно сократилась и составила 15077 человек.

В 2009 году проведение полевых работ было осложнено большим количеством отказов, особенно это касалось «сельской» местности. В итоге даже часть заполненных анкет в результате проверки была забракована. В 2019 году полевые работы проходили легче, сбор анкет с учетом сложностей первого «среза» удалось оптимизировать за счет увеличения числа интервьюеров и методической проработки уже известных проблем. Предварительный расчет выборки с учетом заявленных в программе исследования гипотез, а также численности и характеристик генеральной совокупности при доверительной вероятности $95 \%$ и доверительном интервале $\pm 3,5 \%$ в 2009 году составил 376 человек, в 2019 году - 375 человек. По факту проведенных полевых работ и сортировки бракованных анкет в анализ 2009 года была принята 301 анкета, в 2019 году - 360 анкет.

Городское и сельское население (от 18 лет) опрашивалось как в 2009-м, так и в 2019 году в соответствии с квотами по полу и возрасту. Квоты по полу и возрасту для городского и сельского населения рассчитывались 
отдельно, при этом использовались данные из Паспорта Кирилловского муниципального района за 2007 и 2017 годы. Опросы проходили в соответствии с маршрутными листами в местах проживания респондентов с привлечением интервьюеров. На заполнение каждой анкеты в среднем уходило 15-20 минут.

Исследовательская группа вместе с командой интервьюеров проживала в Кириллове в течение трех недель, делая заметки и ведя дневники наблюдения за городом и его жителями. Выезды в населенные пункты района также сопровождались соответствующими заметками. По завершении каждого дня проводились коллективные обсуждения результатов наблюдения, опроса, что также фиксировалось.

Цифровизация и цифровая экономика: к определению понятий. В связи с определением цифровой экономики, как правило, вспоминается канадский ученый Д. Тэпскотт, который впервые предложил толкование данного понятия [36], Н. Негропонте [30], основавший медиалабораторию в Массачусетском технологическом институте, и Всемирный банк, который также дал определение цифровой экономики, говоря о ней как о «некой системе совокупных отношений экономики, социальной сферы и культуры, основанных на использовании цифровых информационно-коммуникационных технологий» [5, с. 133].

О самом процессе цифровизации можно говорить в широком и узком смысле. В широком смысле цифровизация - это влияние взаимосвязанных цифровых технологий на все сферы жизни общества: социальную, экономическую, политическую, культурную. В узком - это непосредственно сама деятельность, связанная с цифровыми технологиями.

Ряд исследователей полагают, что цифровизация затрагивает не только социальную, но и личностную сферу индивида и влияет на изменение потребностей, где базовым становится информационный обмен (исследование Digital Society Index 2019).

K настоящему времени сформирован ряд признанных международных индексов, с помощью которого оценивается динамика развития цифровизации в той или иной стране мира. Например, в связи с этим можно вспомнить исследование Digital Economy and Society Index (DESI), определяющее рейтинг страны по степени вовлеченности населения в цифровую экономику, или IDI - индекс развития информационно-коммуникационных технологий Международного союза электросвязи, где в качестве основных выступают три субиндекса - доступ, навыки, использование.

Еще один индекс оценки e-Government Development Index (является одним из ключевых индикаторов развития информационного общества в странах мира) был предложен Организацией Объединенных Наций, согласно которому в 2018 году Россия поднялась на 32-е место в мире по уровню готовности правительства использовать информационно-коммуникационные технологии в целях оказания услуг населению.

В литературе также встречается термин «цифровая трансформация». Выделяют три основные трактовки данного термина. Первая сводится к тому, что цифровая трансформация - это эволюционный процесс, который развивается десятилетия, и каждая новая технология добавляет ему новые стадии. Вторая состоит в том, что цифровую трансформацию следует связывать с определенным этапом развития технологий, при этом с появлением облачных вычислений, мобильных устройств, больших данных этот процесс становится синергетическим, когда его конечный эффект - нечто большее, чем просто сумма составляющих [38, 2-5]. Наконец, в рамках третьего подхода утверждается, что цифровая трансформация актуальна для любой компании/индустрии, даже если та не связана напрямую с сетевой реальностью.

В настоящее время проблематику цифровизации изучает целый ряд исследовательских центров в России: Фонд «Общественное мнение» (регулярные замеры в рамках исследовательского проекта «СМИ и Интернет»), Всероссийский центр изучения общественного мнения (исследования влияния различных аспектов цифровизации на социум, а также экпертные дискуссии о роли цифровизации в развитии России и разработка интегральных индексов развития страны, включающих влияние цифровизации), исследовательский центр консалтинговой компании PwC (занимается оценкой цифровой трансформации 
российских компаний и доверия российского бизнеса к цифровым технологиям, исследованием «Digital trust insights»).

Еще один исследовательский центр, изучающий влияние цифровизации на различные социальные и экономические процессы в общероссийском масштабе, - Московская школа управления «Сколково». Сотрудники данного исследовательского центра представили проект «Цифровая Россия», в котором оценили уровень цифрового развития российских регионов. В рамках индекса было разработано семь субиндексов: 1) нормативное регулирование и административные показатели цифровизации; 2) специализированные кадры и учебные программы; 3) наличие и формирование исследовательских компетенций и технологических заделов, включая уровень научно-исследовательских и опытно-конструкторских работ; 4) информационная инфраструктура; 5) информационная безопасность; 6) экономические показатели цифровизации; 7) социальный эффект от внедрения цифровизации. Субиндексы, в свою очередь, оцениваются через субфакторы, которыми в настоящем исследовании выступают события, факты и иная информация, полученная из открытых источников.

Наконец, необходимо упомянуть Высшую школу экономики, которая активно работает в рассматриваемой тематике. Данный исследовательский центр представил проект «Цифровизация в малых и средних городах России».

На базе Православного Свято-Тихоновского гуманитарного университета цифровизация изучается в контексте ее рисков, прежде всего, духовно-нравственных, что нашло отражение в международной исследовательской работе с рядом азиатских и европейских исследовательских центров [19].

Основные черты процесса цифровизации следующие: 1) процесс цифровизации охватывает все сферы жизнедеятельности общества, начиная прежде всего с экономической; 2) процесс цифровизации меняет структуру общества с вертикально ориентированных институтов на горизонтальные сети [13]; 3) основным источником власти и влияния становится генерирование, обработка и передача информации; 4) сама социальная реальность становится тождественна социальной интернет-реальности [12]; 5) меняются также представления о времени и пространстве, которые сжимаются; 6) сам процесс цифровизации проходит не только этапы революции, но и стадии собственной эволюции, одними из которых становятся «Интернет вещей» (веб 4.0), развитый искусственный интеллект (веб 5.0) и активная роботизация [35]; 7) существенно меняется набор технологий продвижения цифровизации, например, появляется технология конструирования виртуальных объектов человеком с привнесением в них аксиологических черт и смыслов. Таким образом, мы имеем дело с процессом, который кардинально меняет привычную нам социальную реальность, трансформируя в том числе традиционные, привычные нам социальные институты.

Цифровизация и Кирилловский район. В нашем исследовании приняли участие как мужчины (45\%), так и женщины (55\%), почти всех возрастных групп населения, кроме тех, кто младше 18 лет. Доминирующей возрастной группой стали респонденты, чей возраст старше 55 лет, их доля повысилась с $34 \%$ в 2009 году до $50 \%$ в 2019 году, что соответствует процессам, происходящим в области в целом [6].

За последние десять лет произошло не только заметное старение населения Кирилловского района, но и сократилась численность населения в группах от 18 до 24 и от 35 до 44 лет, то есть экономически наиболее активных жителей района. Неудивительно поэтому, что у большинства опрошенных нами респондентов (40\%) основным источником дохода является пенсия. Доход остальных групп населения формируется из занятости в качестве рабочих (18\%), специалистов (16\%), служащих непроизводственной сферы (7\%), руководителей (5\%). Безработные среди респондентов составили $4 \%$, что ниже уровня безработицы по Вологодской области в целом $(5,4 \%)$. Таким образом, можно сделать вывод о том, что заметная часть населения района живет за счет государственных и бюджетных средств, при этом в сравнении с 2009 годом доля пенсионеров выросла на $10 \%$, специалистов - на $6 \%$, сократилась доля рабочих и служащих на $7 \%$ и $8 \%$ соответственно, что может свидетельствовать как 
о деиндустриализации района в целом, так и о появлении новых рабочих мест в иных сферах (например, туризме).

При этом обращает на себя внимание тот факт, что за последние десять лет уровень дохода населения Кирилловского района заметно повысился: сократилось число тех, кто испытывал трудности в повседневных расходах, кому не хватало денег даже на еду, увеличилась доля тех, кто имеет средства на все необходимое.

На это же указывают данные вопроса об изменении уровня жизни в целом. Согласно результатам, жизнь респондентов по их субъективной оценке не претерпевает в этом смысле каких-либо серьезных изменений, так как не наблюдается существенного снижения уровня жизни и его роста. Видимо, происходит стагнация жизни, ее крен в сторону социально интертного поведения, которое является не только общим коллективным чувством и образом жизни, но и простимулированным внешними условиями положением населения. О чем, кстати, косвенно свидетельствуют данные другого вопроса на удовлетворенность жителей Кириллова и Кирилловского района различными сферами жизнеобеспечения.

За последние десять лет значительно поменялась картина социально-экономичес- кой жизни района в целом, где наибольшую удовлетворенность среди населения стали приобретать такие позиции, как обеспечение магазинов продовольствием, удовлетворенность культурной сферой и возможностями проведения своего досуга, тогда как в меньшей - услугами связи, обеспечением магазинов одеждой.

Отдельной строкой стоит отметить изменения, произошедшие в транспортной системе района, удовлетворенность которой снизилась с 56\% в 2009 году до 19\% в 2019 году, что может косвенно говорить как о низком качестве транспортных услуг, так и об ограничениях передвижения населения, снижении уровня его мобильности.

В условиях намеченной модернизации и стратегии пространственного развития РФ подобные процессы могут указывать в том числе на то, что отдельные регионы не стимулируют к развитию, а напротив, приводят к затуханию социальной жизни и активности населения. Можно, конечно, отметить, что развитая система транспортного сообщения и услуг связи не вполне необходимы в регионе, где основная масса населения пенсионеры, но тогда вслед за этим стоило бы признать, что значительная часть малых городов будет вынуждена жить в стиуации постепенного вымирания и упадка.

\section{Удовлетворенность различными сферами жизнеобеспечения в Кириллове и Кирилловском районе в 2009 и 2019 гг.}

Таблица 1

\begin{tabular}{|l|c|c|}
\hline & 2009 г. & 2019 г. \\
\hline Удовлетворенность услугами связи & $82,50 \%$ & $76 \%$ \\
\hline Удовлетворенность обеспечением магазинов продуктами & $81,60 \%$ & $78 \%(1$ позиция) \\
\hline Удовлетворенность обеспечением магазинов одеждой & $78 \%$ & $50 \%$ \\
\hline Удовлетворенность транспортной системой & $56 \%$ & $19 \%$ \\
\hline Удовлетворенность культурной сферой & $49 \%$ & $78 \%$ \\
\hline Удовлетворенность возможностями проведения своего досуга & $48 \%$ & $58 \%$ \\
\hline Удовлетворенность школьным образованием & $44 \%$ & $46 \%$ \\
\hline Удовлетворенность медицинским обслуживанием & $36,60 \%$ & $35 \%$ \\
\hline Удовлетворенность социальными пособиями & $33 \%$ & $31 \%$ \\
\hline Удовлетворенность ценами на жилье & $30 \%$ & $20 \%$ \\
\hline Удовлетворенность коммунальным обслуживанием & $27 \%$ & $35 \%$ \\
\hline Удовлетворенность трудоустройством & $25 \%$ & $20 \%$ \\
\hline Удовлетворенность заработной платой & $23 \%$ & $23 \%$ \\
\hline
\end{tabular}


На этом фоне весьма показательны данные относительно удовлетворенности населения мобильной и интернет-связью. Отметим, что замер этих двух позиций делался только в 2019 году, поэтому мы не смогли сделать сравнительный анализ.

Прежде всего наблюдаются высокие проценты тех, кто удовлетворен мобильной связью; заметно меньше тех, кто удовлетворен интернет-связью. Напомним, что одним из основных субиндексов при оценке развития информационно-коммуникационных технологий является как раз доступ населения к таким средствам связи, как Интернет и мобильные телефоны.

Как отмечается в исследовании ВШЭ «Цифровизация в малых и средних городах России», уровень удовлетворенности интернет-связью опосредованно влияет на качество жизни. Это проявляется через такие критерии, как уровень благосостояния и занятость (возможность удаленной работы через Интернет), потребление услуг (экономия на традиционных услугах, например, междугородней телефонии и одновременное потребление новых цифровых услуг), доступ к современным образовательным технологиям (в том числе к бесплатным курсам ведущих вузов мира), формирование новых качественных социальных связей (по области интереса, а не по месту проживания).

Всего 68\% опрошенных Кирилловского района используют Интернет в своих повседневных нуждах, что заметно меньше этого же показателя в целом по России (по данным исследования Всероссийского центра изучения общественного мнения, с той или иной периодичностью во Всемирную сеть заходят $81 \%$ жителей России).

При этом покрытие мобильного Интернета в исследуемом районе находится на среднем отраслевом уровне, то есть гово- рить о малой распространенности интернетинфраструктуры не приходится. Интернетом мало пользуются не потому, что он недоступен, а потому, что не видят в этом необходимости, с одной стороны, и обладают низкой цифровой грамотностью, с другой.

При этом ежедневно пользуются Интернетом $56 \%$ опрошенных (что также меньше общероссийского показателя в $65 \%$ в исследовании ВЦИОМ), среди них доминируют респонденты, имеющие среднее (24\%) или высшее образование (20\%), основными возрастными группами среди тех, кто пользуется Интернетом практически ежедневно, являются жители Кириллова и Кирилловского района в возрасте от 30 до 39 лет $(14 \%)$, от 40 до 49 лет $(12 \%)$ и от 50 до 59 лет $(11 \%)$.

Стоит отметить, что $37 \%$ жителей Кириллова и Кирилловского района не пользуются Интернетом вообще, эту группу составили те, кто не пользуется Интернетом никогда, и те, кто пользуется Интернетом реже, чем несколько раз в неделю. Как правило, это люди в возрасте от 60 до 69 лет (12\%), от 70 до 79 лет $(8 \%)$ и от 50 до 59 лет (5\%), имеющие среднее специальное (13\%) или среднее образование (10\%). То есть почти $40 \%$ населения района не включены в процесс цифровизации, что связано в том числе с возрастом и образованием пользователей: чем они старше и менее образованны, тем больше вероятность, что не являются активными пользователями сети.

Если говорить об уровне цифровых компетенций жителей Кирилловского района, то наблюдается следующее: 50\% опрошенных прибегают к Интернету для просмотра сайтов и общения в социальных сетях, 39\% респондентов используют в качестве электронной почты и $36 \%$ используют различные интернет-сервисы (интернет-магазины,

Таблица 2

\section{Удовлетворенность населения Кирилловского района услугами связи в целом, мобильной и интернет-связью. Данные 2009 и 2019 гг.}

\begin{tabular}{|l|c|c|}
\hline & 2009 г. & 2019 г. \\
\hline Удовлетворенность услугами связи & $82,50 \%$ & $76 \%$ \\
\hline Удовлетворенность мобильной связью & - & $85 \%$ \\
\hline Удовлетворенность интернет-связью & - & $56 \%$ \\
\hline
\end{tabular}


электронные банковские и страховые услуги и пр.). Аналогичные данные приводятся и в исследовании ВШЭ «Цифровизация в малых и средних городах России». Структура использования Интернета в малых и крупных городах отличается тем, что в малых городах сеть используется исключительно в коммуникационных целях (использование социальных сетей и электронной почты), в то время как в крупных городах речь идет о вовлечении населения в цифровую экономику через использование интернет-услуг (сервисы заказа и доставки еды, онлайн-покупки, заказ такси онлайн, использование платных интернет-сервисов и т.д.)

При этом в малых городах России госуслуги, предоставляемые через Интернет, являются «точкой входа» населения в цифровую экономику. Это обусловлено постоянным развитием государственных интернет-сервисов, их бесплатностью и удобством пользования.

Госуслугами онлайн в Кирилловском районе пользуются $53 \%$ населения, при этом наиболее популярные госуслуги - это личный кабинет налогоплательщика (31 \% опрошенных), регистрация брака и использование материнского капитала (10\%), получение различных льгот, в том числе санаторного лечения (12\%).

Важно при этом следующее: при наличии почти 40\% тех, кто не пользуется Интернетом вообще, подавляющее большинство жителей Кириллова и Кирилловского района (76\%) выразили свое позитивное отношение к процессу цифровизации, отмечая таким образом не только свое согласие с общественным мнением, но и определенный оптимизм в отношении происходящих процессов. И это несмотря на то, что половина респондентов старше 55 лет, то есть относится к тем группам, кто меньше всего участвует в процессе цифровизации.
Религиозность населения Кириллова и Кирилловского района. Вопросам определения и измерения религиозности в отечественной социологии посвящена масса литературы $[23,21,20,14,15]$. При этом данная дискуссия продолжается до сих пор $[9,17,4$, 29]. В своем исследовании мы руководствовались критерием поведенческой религиозности, говорящей в том числе о степени институциональной принадлежности верующих, и аспектом знания основ вероучения, с которым связывается религиозная идентичность. Это позволило нам, не углубляясь в детали (что не требовалось в данном исследовании, не посвященном сугубо изучению религиозности населения малого города), выделить собственную типологию в соответствии с нашими исследовательскими задачами.

Если говорить о наличии групп верующих и неверующих по самоидентификации в районе в 2009 и 2019 годах, то мы обнаружим, что количественно эти группы стабильны: неверующие составляют, как и 10 лет назад, $19 \%$, верующие - $81 \%$ опрошенных. Вместе с тем при детализации групп ответов обнаруживаются изменения в позициях: в сравнении с 2009 годом несколько возросло количество тех, кто назвал себя «скорее верующим» (то есть сомневающихся), и тех, кто причислил себя к «атеистам». И хотя разница в процентах не превышает $5 \%$, то есть статистически не значима, можно все же обратить внимание на определенное колебание в оценке религиозной позиции.

О своей принадлежности к православному вероисповеданию заявили $83 \%$ опрошенных из тех, кто назвали себя «верующими», что свидетельствует о том, что по конфессиональной самоидентификации значительная часть населения Кириллова и Кирилловского района связывает себя все-таки с православием. Причем этот процент был высок

Таблица 3

Религиозность жителей Кирилловского района Вологодской области в 2009 и 2019 гг.

\begin{tabular}{|l|c|c|}
\hline & 2009 г. & 2019 г. \\
\hline Я верующий & $45 \%$ & $41 \%$ \\
\hline Скорее верующий, чем неверующий & $36 \%$ & $40 \%$ \\
\hline Скорее неверующий, чем верующий & $11 \%$ & $7 \%$ \\
\hline Я атеист & $8 \%$ & $12 \%$ \\
\hline
\end{tabular}


как в 2009, так и в 2019 году (хотя состав населения по возрасту и социальному положению, как было показано ранее, несколько изменился). При этом наблюдаются существенные изменения населения в ритуальном поведении и понимании основ православного вероучения.

За последние десять лет значительно сократилось число тех, кто вообще не посещает или посещает раз в год православные богослужения в храме, кто не соблюдает посты (хотя процент несоблюдающих посты в сравнении с другими показателями остается самым высоким). Таким образом, мы видим, что показатели институциональной религиозности повысились, а это косвенно может свидетельствовать об изменении религиозной ситуации в районе в целом. Отношение к Таинствам и участие в них остается практически неизменным, и непричащающихся (с различной степенью регулярности) почти тот же процент — больше половины опрошенных.

Благодаря проведенному факторному анализу (факторы извлекались методом главных осей с последующим косоугольным облимин-вращением, варимакс с нормализацией Кайзера, мера КМО = 0,61, критерий сферичности Бартлетта $<0,0001)$, удалось выделить несколько групп факторов по критерию собственного значения $>1$. Выделенные факторы объясняют 50\% дисперсии.

С первым фактором коррелируют такие утверждения, как «религия - способ обмана народа», «можно быть православным и не ходить в храм» и «православие обманывает». Назовем этот фактор антирелигиозной позицией индивида.

Со вторым фактором коррелируют утверждения: «я могу обратиться к колдунам», «я регулярно читаю гороскопы», «я хорошо отношусь к православию», «можно быть православным и не ходить в храм». Назовем этот фактор «религиозный синкретизм», то есть смесь традиционно православных представлений и «языческих», с преобладанием интереса к последним.

С третьим фактором коррелирует: вера в Бога-Троицу, в будущее второе пришествие Христа, в существование чудотворных икон, отрицательное отношение к гороскопам. Назовем этот фактор «традиционно православное мировоззрение».

Таким образом, мы видим, что среди опрошенных православных верующих (тех, кто назвал себя таковыми) есть те, кто

Таблица 4

Вероисповедание жителей Кирилловского района Вологодской области в 2009 и 2019 гг.

\begin{tabular}{|l|c|c|}
\hline & 2009 г. & 2019 г. \\
\hline Православие & $76,70 \%$ & $83 \%$ \\
\hline Христианство и другие конфессии & $4,30 \%$ & $2,50 \%$ \\
\hline Затрудняюсь ответить & $16,70 \%$ & $14,50 \%$ \\
\hline
\end{tabular}

Таблица 5

Ритуальное поведение жителей Кирилловского района Вологодской области в 2009 и 2019 гг.

\begin{tabular}{|c|c|c|}
\hline & 2009 г. & 2019 г. \\
\hline \multicolumn{3}{|c|}{ Посещение богослужений в храме } \\
\hline Реже одного раза в год + не посещал никогда & $47 \%$ & $32,60 \%$ \\
\hline \multicolumn{3}{|c|}{ Соблюдение постов } \\
\hline Не соблюдаю постов & $83 \%$ & $63 \%$ \\
\hline \multicolumn{3}{|c|}{ Исповедь и причастие } \\
\hline Не исповедуюсь, не причащаюсь & $57 \%$ & $53,50 \%$ \\
\hline
\end{tabular}


Таблица 6

Факторный анализ ответов на вопрос о знании своей веры и об отношении к православию жителей Кирилловского района Вологодской области, 2019 г.

\begin{tabular}{|l|c|c|c|}
\hline & \multicolumn{3}{|c|}{ Фактор } \\
\cline { 2 - 4 } & 1 & 2 & 3 \\
\hline Я верю в Бога-Троицу & 0,223 & $-0,207$ & 0,63 \\
\hline Религия — способ обмана народа & 0,815 & $-0,037$ & $-0,018$ \\
\hline Я обращался колдунам & 0,073 & 0,73 & 0,074 \\
\hline Я верю в будущее второе пришествие Христа & 0,03 & 0,084 & 0,57 \\
\hline Я регулярно читаю гороскопы & 0,145 & 0,744 & $-0,010$ \\
\hline Я верю в существование чудотворных икон & $-0,115$ & 0,081 & 0,607 \\
\hline Можно быть православным и не ходить в храм & 0,526 & 0,314 & 0,013 \\
\hline Православие обманывает & 0,787 & 0,157 & 0,067 \\
\hline Я хорошо отношусь к православию & $-0,421$ & 0,342 & 0,447 \\
\hline
\end{tabular}

Содержание религиозных представлений жителей Кирилловского района Вологодской области в 2009 и 2019 гг.

\begin{tabular}{|c|c|c|}
\hline & 2009 г. & 2019 г. \\
\hline \multicolumn{3}{|c|}{ Я обращался или готов обратиться за помощью к гадалкам, колдунам, магам } \\
\hline Полностью и скорее согласен & $11 \%$ & $6 \%$ \\
\hline \multicolumn{3}{|c|}{ Религия — это способ обмана народа» } \\
\hline Полностью и скорее согласен & $17 \%$ & $13,20 \%$ \\
\hline \multicolumn{3}{|c|}{ Я регулярно читаю гороскопь, астрологические прогнозы } \\
\hline Полностью и скорее согласен & $32 \%$ & $25,40 \%$ \\
\hline \multicolumn{3}{|c|}{ Православие обманывает человека, уводит его от житейских забот в иллюзорный мир } \\
\hline Полностью и скорее согласен & $18 \%$ & $7,60 \%$ \\
\hline \multicolumn{3}{|c|}{ В будущем мир ожидает Второе Пришествие Христа } \\
\hline Полностью и скорее согласен & $49 \%$ & $37,20 \%$ \\
\hline \multicolumn{3}{|c|}{ Можно быть православным и не ходить в ијерковь, не соблюдать ијерковнье обрядыл } \\
\hline Полностью и скорее согласен & $74 \%$ & $72,30 \%$ \\
\hline \multicolumn{3}{|c|}{ Я верю в Святую Троииу } \\
\hline Полностью и скорее согласен & $79 \%$ & $76,10 \%$ \\
\hline \multicolumn{3}{|c|}{ Сущцествуют чудотворные иконы } \\
\hline Полностью и скорее согласен & $77 \%$ & $80,20 \%$ \\
\hline \multicolumn{3}{|c|}{ Я хорошо отношусь к православной вере } \\
\hline Полностью и скорее согласен & $93,40 \%$ & $93,70 \%$ \\
\hline
\end{tabular}


придерживается антирелигиозной позиции, и те, кто выражает традиционно православную точку зрение. Помимо крайних позиций, есть и промежуточные варианты. Подобный факт указывает на то, что православная религиозность в Кирилловском районе неоднородна. Но что объединяет? Как правило, наличие основного признака - желание либо быть в рамках конфессионального и религиозного поля, либо быть вне его (с разной степенью отрицательного отношения к религии и церкви, иногда и просто индифферентного).

Согласно полученным данным, за последние десять лет произошли некоторые изменения в понимании православной веры и в отношении к ней жителей Кириллова и Кирилловского района. Очевидно, что поменялось отношение к религии и православию в целом: считающих, что религия и в частности православие - способ обмана, стало заметно меньше. Это может свидетельствовать о постепенном уходе советских штампов антирелигиозной идеологии из сознания индивидов.

Вместе с этим остаются процентно неизменными группы тех, кто придерживается традиционных представлений о православных догматах - высок процент «хорошо относящихся» к православию в целом, а также согласных с тем, что они веруют в Святую Троицу, в существование чудотворных икон.
На этом фоне весьма показательно наличие таких (количественно заметных) респондентов, кто считает, что можно быть православным и не ходить в церковь, не соблюдать обряды; таковых было достаточно много как в 2009, так и в 2019 году. Данное представление среди определенной части населения можно считать неизменным и устойчивым, что может говорить о наличии сформировавшейся группы, в которой вера чаще всего не связывается с церковным институтом, более того, может осуществляться помимо него. При этом возникает вопрос, что же понимает население под «быть православным»? Этот вопрос становится еще более актуальным в ситуации, когда за последние десять лет число тех, кто верил в будущее второе пришествие Христа, заметно сократилось с 49\% в 2009 до 37\% в 2019 году. Можно предположить, что подобное сокращение говорит не столько о незнании этого догмата, сколько о понижении уровня доверия к нему.

Еще один вопрос на субъективную оценку степени влияния православной веры на различные аспекты жизни населения Кириллова и Кирилловского района также показал произошедшие изменения за последние годы.

Для начала стоит отметить, что для основной массы опрошенных подобное влияние неактуально. Но тех, кто признает такое влияние, за последние десять лет стало за-

Таблица 8

Самооценка влияния православной веры на различные аспекты жизни населения Кириллова и Кирилловского района Вологодской области в 2009 и 2019 гг.

\begin{tabular}{|c|c|c|}
\hline & 2009 г. & 2019 г \\
\hline \multicolumn{3}{|c|}{$\begin{array}{c}\text { Православная вера влияет на мои представления о семье, } \\
\text { в частности, на количество детей в ней }\end{array}$} \\
\hline Полностью и скорее согласен & $12,60 \%$ & $22,40 \%$ \\
\hline \multicolumn{3}{|c|}{ Православная вера влияет на мое участие в выборах и политическую активность } \\
\hline Полностью и скорее согласен & $10 \%$ & $15 \%$ \\
\hline \multicolumn{3}{|c|}{ Православная вера влияет на проведение досуга } \\
\hline Полностью и скорее согласен & $18 \%$ & $27,80 \%$ \\
\hline \multicolumn{3}{|c|}{ Православная вера влияет на выбор чтения литературы } \\
\hline Полностью и скорее согласен & $15 \%$ & $23,40 \%$ \\
\hline \multicolumn{3}{|c|}{ Православная вера влияет на мои идеаль и приниципь } \\
\hline Полностью и скорее согласен & $23 \%$ & $42 \%$ \\
\hline
\end{tabular}


метно больше. Они отмечали влияние православия как в выборе способов проведения своего досуга, чтения литературы, представлений о семье, так и в формировании идеалов и жизненных принципов в целом. Даже в такой сфере, как политический выбор и голосование, по оценке респондентов, есть подобное влияние, хотя и в меньшей степени, чем в других сферах. Таким образом, можно отметить, что при подавляющем большинстве тех, кто не видит влияния православия на свою жизнь, число тех, кто разделяет принципы православной веры (и скорее всего, некую традицию, устойчивые представлений о ней), возросло.

В итоге можно отметить, что при подавляющем большинстве тех опрошенных, кто назвал себя «православными верующими», степень их религиозности и воцерковленности различна: от традиционно верующих до носителей антирелигиозных воззрений, от верующих в Святую Троицу до считающих, что спасение возможно вне таинств Церкви, при этом хорошо относящихся к православию в целом и в общей своей массе не верящих во второе пришествие Христа, отходящих от атеистических представлений советского прошлого о религии как об опиуме для народа и вместе с тем не признающих влияния православия на свою жизнь. Подобный микс складывается как в результате активной православной проповеди, так и в результате влияния уже имеющихся представлений и верований.

Цифровизация и православная религиозность малого города. Одной из основных гипотез нашего исследования была гипотеза о влиянии религиозного фактора на отношение и оценку цифровизации населением, на их поведенческие «цифровые» практики. В связи с этим мы в первой части статьи подробным образом описали, как проходит процесс цифровизации в малом городе в целом (в условиях его стагнации и сокращения молодого населения), также дали оценку преимущественно православной религиозности, которая не только неоднородна, но и в ряде случаев квазирелигиозна.

В этом разделе мы предпринимаем попытку проверить наличие связи между установленной нами православной религиозностью населения Кириллова и Кирилловского района и процессами цифровизации, осуществляемыми населением в малом городе. С этой целью был использован коэффициент корреляции Спирмена, позволяющий оценить тесноту связи между двумя рядами сопоставляемых количественных показателей. Напомним, что коэффициент корреляции может принимать значения от минус единицы до единицы, причем при rs $=1$ имеет место строго прямая связь, а при rs $=-1-$ строго обратная связь, если коэффициент корреляции равен нулю, то связь между величинами практически отсутствует.

Прежде чем перейти к процедуре проверки корреляции, мы выделили в отдельную группу тех, кого можно назвать религиозными в той или иной степени, они составили $34,7 \%$ опрошенных. К группе «религиозные люди» нами были отнесены все те, кто:

- посещают православные храмы несколько раз в неделю и несколько раз в месяц, причащаются не менее 4 раз в год и соблюдают хотя бы 4 многодневных поста (таковых $4,2 \%$ в выборочной совокупности);

- посещают храмы несколько раз в год, причащаются не менее раза в год и стараются соблюдать Великий пост (таковых 5,8 \% в выборочной совокупности);

- посещают храмы реже одного раза в год, причащаются реже одного раза в год, не соблюдают посты (таковых 24,7\% в выборочной совокупности).

Bce прочие, кто никогда не посещали храмы или вообще затруднились ответить на этот вопрос, никогда не причащались и не исповедовались или не знакомы с этим обрядом и не соблюдают посты, были отнесены нами в группу «нерелигиозные люди» и исключены из дальнейшего анализа.

В итоге всех проделанных процедур корреляция признаков осуществлялась в сравнении «религиозность» и «использование Интернета» (вопрос №17 в анкете), «религиозность» и «пользование госуслугами» (вопрос №18 в анкете). Были получены следующие значения корреляции Спирмена (см. таблицу 9).

Согласно полученным данным, мы не можем говорить о наличии как прямой, так и обратной связи между коррелируемыми признаками. Связь между величинами практически отсутствует, что свидетельствует о том, что фактор религиозности не влияет на отноше- 
Таблица 9

Значение корреляции признаков «религиозность» и «использование Интернета», «религиозность» и «пользование госуслугами»

\begin{tabular}{|l|c|}
\hline \multicolumn{1}{|c|}{ Сопоставляемые количественные показатели } & $\begin{array}{c}\text { Значение корреляции } \\
\text { Спирмена }\end{array}$ \\
\hline Пользуюсь интернетом / «Религиозность» & 0,054 \\
\hline Интернет для просмотра сайтов / «Религиозность» & $-0,033$ \\
\hline Интернет для электронной почты / «Религиозность» & $-0,080$ \\
\hline Интернет для соцсети / «Религиозность» & $-0,044$ \\
\hline Интернет для сервисов / «Религиозность» & $-0,038$ \\
\hline Не пользуюсь интернетом / «Религиозность» & 0,096 \\
\hline Госулуги. Личный кабинет налогоплательщика / «Религиозность» & $-0,093$ \\
\hline Госулуги. Регистрация брака, ребенка, маткапитал / «Религиозность» & $-0,110$ \\
\hline Госулуги. Установление пенсии, пособия / «Религиозность» & $-0,145$ \\
\hline Госулуги. Запись в детский сад, школу / «Религиозность» & $-0,084$ \\
\hline Госуслуги. Проверка судебной задолжности / «Религиозность» & $-0,034$ \\
\hline Не пользуюсь госулугами / «Религиозность» & 0,082 \\
\hline
\end{tabular}

ние и оценку цифровизации и на поведенческие «цифровые» практики населения.

Заключение. Главный вывод нашей работы состоит в том, что религиозность населения Кириллова и Кирилловского района не оказывает влияние на отношение основной части населения данной территории к процессу цифровизации.

Подобный итог может быть объяснен несколькими причинами. Во-первых, это можно связать с малочисленностью самой группы православных верующих.

Во-вторых, в самом исследовании не были заложены вопросы, требующие полярных оценок, такие, например, как чипирование населения и т.д., которые, возможно, могли бы дать зависимости. Особенно, если бы изучались не сами «цифровые» практики и участие населения в них, от которых в общем никуда не деться и это в определенном смысле бывает удобно, а изучались бы идеологические штампы (например, апокалипсически окрашенные риски и последствия).

Третья причина - цифровизация в ее умеренном варианте, который мы исследовали, - не является объектом полярных оценок в общественном дискурсе и в христианстве, отсюда следует, что сам процесс цифровизации у православных верующих не вызывает опасений и тревоги.

Четвертое объяснение отчасти находим в исследовании «Московской школы социально-экономических наук» 2016 года, в ходе которого был выявлен значительный «технологический оптимизм» жителей России [39]. То есть речь идет в целом о достаточно высокой лояльности россиян к инновациям и технологиям. В социологической литературе подобное явление объясняется через понятие традиционалистский модернизм $[3,2,7]$, которым характеризуется принятие всего, что связано с научно-техническим прогрессом до тех пор, пока это не вступает в противоречие с разделяемыми принципами и ценностями [1]. Если этого не происходит, то технический прогресс только приветствуется.

Основной причиной торможения процесса цифровизации в малых городах и периферийных территориях, таких как Кириллов и Кирилловский район, является стагнирование этих территорий, депопуляция и старение населения. В свою очередь, это проявляется не только в ухудшении транспортного сообщения района и услуг связи, активно задействованных в процессе циф- 
ровизации, но и в ограниченном доступе населения к качественной интернет-связи, в отсутствии нужных компетенций и «цифровой» грамотности.

У той части населения, которая пользуется Интернетом, пока не происходит «вторичной цифровизации», то есть нет привычки пользоваться Интернетом не только ради развлечения и общения, но и в рабочих и повседневных нуждах. Надо признать, что для последнего пока слабо сформированы как сами навыки, так и мало подготовлена сама среда и соответствующие инфраструктуры. Наиболее успешными в этом смысле оказались госуслуги, через которые население малого города и приобщается постепенно к процессу цифровизации.

\section{Литература}

1. Аксенова О.В. Субъект социального действия в современном развитии России: актор, агент, никто? // Вестник Института социологии. - 2020. - Т. 11. - №2. - С.37-53. DOI: $10.19181 /$ vis.2020.11.2.640.

2. Аксенова О.В., Халий И.А. Современное развитие. К постановке темы исследования // Вестник Института социологии. 2018. — №24. - C. 13-26. - DOI: https://doi. org/10.19181/vis.2018.24.1.492.

3. Андреев А.Л. Российский социум как «другая Европа» // Общественные науки и современность. - 2013. - №3. - С. 70-79.

4. Беликова Е.О. Поиски стратегии социологического изучения религиозной идентичности // Мониторинг общественного мнения: Экономические и социальные перемены. - 2018. - №2. - C. 116-127. - DOI: 10.14515/monitoring.2018.2.05.

5. Богданов В.С. Организационно-методологические аспекты дистанционного исследования проблем цифровизации регионов с различным уровнем социокультурной модернизации. Часть 2 // Социологическая наука и социальная практика. - 2020. T. 8. - №1. - C. 131-149. - DOI:10.19181/ snsp.2020.8.1.7100.

6. Будилов А.П., Калачикова О.Н. Миграция и переселенческие установки жителей Вологодской области // Проблемы развития территории. - 2020. — №2 (106). — С. 108-119. DOI: $10.15838 /$ ptd.2020.2.106.8.
7. Вебер А.Б. Парадоксы современного развития: человечество у развилки истории // Вестник Института социологии. 2018. - №24. - C. 52-75. - DOI: https://doi. org/10.19181/vis.2018.24.1.494.

8. Деготь E. Пространственные коды «русскости» в искусстве XIX века [Электронный ресурс] // Отечественные записки. - 2002. - №6. - Режим доступа: https://magazines.gorky.media/oz/2002/6/ prostranstvennye-kody-russkosti-v-iskusstvexix-veka-fragment.html (Дата обращения: 30.06.2020).

9. Емельянов Н.Н. Парадокс религиозности: откуда берутся верующие? // Мониторинг общественного мнения: Экономические и социальные перемены. 2018. - №2. - C. 32-48. - DOI: 10.14515/ monitoring.2018.2.02.

10. Забаев И.В. Религия и экономика: можем ли мы все еще опираться на Макса Вебера? // Социологическое обозрение. 2018. - T. 17. - №3. - C. 107-148.

11. Ильин В. И. Человек на старом Русском Севере: между свободой воли и структурным принуждением (исторический очерк в терминах экзистенциальной социологии)// Мир России. - 2020. - Т. 29. - №3. - С. 6-27. DOI: 10.17323/1811-038X-2020-29-3-6-27.

12. Кастельс M. Галактика Интернет: Размышления об Интернете, бизнесе и обществе. Пер. с англ. - Екатеринбург: «У-Фактория», 2004. - $328 \mathrm{c}$.

13. Кастельс М. Информационная эпоха: экономика, общество и культура. - М.: ГУ ВШЭ, 2000. - $608 \mathrm{c}$.

14. Лебедев С.Д. Парадоксы религиозности в мире Позднего Модерна // Социологические исследования. - 2010. - №12.

15. Лебедев С.Д., Сухоруков В.В. Тесный путь не туда? // Социологические исследования. - 2013. - №1. - С. 118-127.

16. Малые города в социальном пространстве России: монография [Электронный ресурс] / А. Ю. Ардальянова, П. В. Бизюков, Р.Г. Браславский и др. // Отв. ред. В.В. Маркин, М.Ф. Черныш; предисл. ак. М.К. Горшков. - М.: ФНИСЦ РАН, 2019. - 545 c. - DOI: 10.19181/monogr. 978-5-89697-323-2.2019. - Режим доступа: https://www.isras.ru/index.php?page_ $\mathrm{id}=1198 \& \mathrm{id}=7751$. 
17. Маркин К. В. Между верой и неверием: непрактикующие православные в контексте российской социологии религии // Мониторинг общественного мнения: Экономические и социальные перемены. 2018. - №2. - C. 266-282. - DOI: 10.14515/ monitoring.2018.2.16.

18. Масло Р.Е. Определение понятия «Малый город» в глобальной системе мирохозяйственных связей // Бизнес Информ. 2014. — №10. - C. 14-17.

19. Рязаниеев И. П., Писаревский В.Г. Философия раннего христианства и вызовы цифровизации. Международная конференция «Философия раннего христианства в эпоху цифровизации», Католический университет Фужэнь (Тайвань, 6-7 декабря 2019 г.)// Журнал «Экономическая социология». 2020. — T. 21. — №2. - C. 91-98.

20. Узланер Д.А. Секуляризация как социологическое понятие // Социологические исследования. - 2008. - №8.

21. Филатов С.Б., Лункин Р.Н. Статистика российской религиозности: магия цифр и неоднозначная реальность // Социологические исследования. - 2005. - №6.

22. Хариссон Л. Евреи, конфуцианцы и протестанты: культурный капитал и конец мультикультурализма [Электронный ресурс]// Доклад на международной конференции НИУ ВШЭ. - 2009. - Режим доступа: https://www.hse.ru/news/science/7075536.html (Дата обращения: 10.05.2020).

23. Чеснокова В.Ф. Тесным путем. Процесс воцерковления населения России в конце XX века. - М., 2005. - 304 с.

24. Шабаев Ю.П., Жеребчов И.Л., Журавлев П.С. «Русский Север»: культурные границы и культурные смыслы // Мир России. - 2012. - №4. - С. 134-153.

25. Ясин Е.Г. Модернизация российской экономики: что в повестке дня // Экономический журнал Высшей школы экономики. 2001. - T. 5. - №2. - С. 158-178.

26. Ясин Е., Яковлев А. Конкурентоспособность и модернизация российской экономики // Вопросы экономики. - 2004. №7. - C. 4-34.

27. Guimarães M., Nunes. L., Barreira A., Panagopoulos $T$. What makes people stay in or leave shrinking cities? An empirical study from Portugal // European Planning Studies. -
2016. — Vol. 24. — №9. - Pp. 1684-1708. DOI: $10.1080 / 09654313.2016 .1177492$.

28. Harvey D. Spaces of hope. - Edinburgh University Press, Edinburgh, 2000. - 310 p.

29. Lebedev S., Blagoevic M., Pokaninova E. Value- and Reflection-based Approach to Indicators of Orthodox Religiosity of the Population [Electronic resource] // Stanovništvo. (In Serbian). — 2020. — №58 (1). — Pp. 47-61. URL: http://idn.org.rs/ojs3/stanovnistvo/index. $\mathrm{php} / \mathrm{STNV} /$ article/view/381 (Date accessed: 08.08.2020).

30. Negroponte N. Being Digital. - NY: Knopf, 1995. - $256 \mathrm{p}$.

31. Pollak D. Renaissance des Religiösen? Veränderungen auf dem religiösen Feld in ausgewählten Ländern Ost- und Ostmitteleuropas // Archiv für Sozialgeschichte. — 2011. №51. - P. 116.

32. Ryan B.D. Design after Decline: How America Rebuilds its Shrinking Cities. - Philadelphia: University of Pennsylvania Press, 2012. - 288 p.

33. Sassen $S$. The global city: New York, London, Tokyo [Electronic resource]. - Princeton University Press, Princeton, NJ, 2001. — URL: http://dx.doi.org/10.1515/9781400847488.

34. Scott A., Storper M. Regions, globalization, development // Regional Studies. 2007. — №37 (6-7). — Pp. 579-593. — DOI: 10.1080/0034340032000108697a.

35. Skinner $C$. Digital human. The fourth revolution of humanity includes everyone. Marshall Cavendish International (Asia) Pte Ltd, 2018. - 328 p.

36. Tapscott $D$. The Digital Economy: Promise and Peril In The Age of Networked Intelligence. - NY: McGraw-Hill,1994. $368 \mathrm{p}$.

37. Van den Berg L., Drewett R., Klaasen L. Urban Europe: A Study of Growth and Decline. - Pergamon, Oxford, 1982. - $162 \mathrm{p}$.

38. Weill P., Woerner $S$. Digital business transformation. - Harvard Business Review Press (USA), 2018. - $260 \mathrm{p}$.

39. Исследование поведенческих и институциональных предпосылок технологического развития регионов РФ [Электронный pecypc]. - Режим доступа: https://www.rvc. $\mathrm{ru} /$ upload/iblock/0e8/attitudes_to_technologies and_innovations_in_Russiapdf (Дата обращения: 09.02.2021). 


\section{References}

1. Aksenova $O . V$. Sub'ekt social'nogo dejstvija v sovremennom razvitii Rossii: aktor, agent, nikto? [The subject of social action in the modern development of Russia: actor, agent, nobody?] // Vestnik Instituta sociologii [Bulletin of the Institute of Sociology]. - 2020. Vol. 11. — №2. - Pp. 37-53. - DOI: 10.19181/ vis.2020.11.2.640.

2. Aksenova O.V., Halij I.A. Sovremennoe razvitie. $\mathrm{K}$ postanovke temy issledovanija [Modern development. To the formulation of the research topic] // Vestnik Instituta sociologii [Bulletin of the Institute of Sociology]. 2018. - №24. - Pp. 13-26. - DOI: https:// doi.org/10.19181/vis.2018.24.1.492.

3. Andreev A. L. Rossijskij socium kak «drugaja Evropa» [Russian society as «another Europe»] // Obshhestvennye nauki i sovremennost' [Social Sciences and modernity]. — 2013. №3. - Pp. 70-79.

4. Belikova E.O. Poiski strategii sociologicheskogo izuchenija religioznoj identichnosti [The search for a strategy for the sociological study of religious identity] // Monitoring obshhestvennogo mnenija: Jekonomicheskie i social'nye peremeny [Monitoring of public opinion: Economic and social changes]. — 2018. №2. - Pp. 116-127. - DOI: 10.14515/monitoring.2018.2.05.

5. Bogdanov V.S. Organizacionno-metodologicheskie aspekty distancionnogo issledovanija problem cifrovizacii regionov s razlichnym urovnem sociokul'turnoj modernizacii. Chast' 2 [Organizational and methodological aspects of remote research of the problems of digitalization of regions with different levels of socio-cultural modernization. Part 2] // Sociologicheskaja nauka i social'naja praktika [Sociological science and social practice]. - 2020. - Vol. 8. №1. - Pp.131-149. - DOI:10.19181/ snsp.2020.8.1.7100.

6. Budilov A.P., Kalachikova O.N. Migracija i pereselencheskie ustanovki zhitelej Vologodskoj oblasti [Migration and resettlement attitudes of residents of the Vologda region] // Problemy razvitija territorii [Problems of territory development]. - 2020. - №2 (106). - Pp. 108-119. DOI: $10.15838 /$ ptd.2020.2.106.8.

7. Veber A.B. Paradoksy sovremennogo razvitija: chelovechestvo u razvilki istorii
[Paradoxes of modern development: humanity at the fork of history] // Vestnik Instituta sociologii [Bulletin of the Institute of Sociology]. 2018. - №24. - Pp. 52-75. - DOI: https:// doi.org/10.19181/vis.2018.24.1.494.

8. Degot'E. Prostranstvennye kody «russkosti» $\mathrm{v}$ iskusstve XIX veka [Spatial codes of «Russianness» in the art of the XIX century] [Jelektronnyj resurs] // Otechestvennye zapiski. — 2002. - №6. - URL: https://magazines.gorky.media/oz/2002/6/prostranstvennyekody-russkosti-v-iskusstve-xix-veka-fragment. html (Date accessed: 30.06.2020).

9. Emel'janov N.N. Paradoks religioznosti: otkuda berutsja verujushhie? [The paradox of religiosity: where do believers come from?] // Monitoring obshhestvennogo mnenija: Jekonomicheskie i social'nye peremeny [Monitoring public opinion: Economic and social changes]. - 2018. — №2. - Pp. 32-48. — DOI: 10.14515/monitoring.2018.2.02.

10. ZabaevI. $V$. Religija i jekonomika: mozhem li my vse eshhe opirat'sja na Maksa Vebera? [Religion and economics: can we still rely on Max Weber?] // Sociologicheskoe obozrenie [Sociological review]. — 2018. - Vol. 17. №3. - Pp. 107-148.

11. Il'in V.I. Chelovek na starom Russkom Severe: mezhdu svobodoj voli i strukturnym prinuzhdeniem (istoricheskij ocherk $\mathrm{v}$ terminah jekzistencial'noj sociologii) [A man in the Old Russian North: between free will and structural coercion (a historical essay in terms of existential sociology)] // Mir Rossii [World of Russia]. 2020. - Vol. 29. - №3. - Pp. 6-27. - DOI: 10.17323/1811-038X-2020-29-3-6-27.

12. Kastel's $M$. Galaktika Internet: Razmyshlenija ob Internete, biznese i obshhestve. Per. s angl. [Galactica Internet: Reflections on the Internet, Business and Society. Trans. from English]. Ekaterinburg: «U-Faktorija», 2004. - 328 p.

13. Kastel's $M$. Informacionnaja jepoha: jekonomika, obshhestvo i kul'tura [The Information age: economy, society and culture]. - Moscow: GU VShJe, 2000. - 608 p.

14. Lebedev S.D. Paradoksy religioznosti $\mathrm{v}$ mire Pozdnego Moderna [Paradoxes of religiosity in the world of Late Modernity] // Sociologicheskie issledovanija [Sociological research]. — 2010. — №12.

15. Lebedev S.D., Suhorukov V.V. Tesnyj put' ne tuda? [A tight path is not there?] // So- 
ciologicheskie issledovanija [Sociological research]. — 2013. — №1. — Pp. 118-127.

16. Malye goroda $\mathrm{v}$ social'nom prostranstve Rossii: monografija [Small cities in the social space of Russia: a monograph] [Jelektronnyj resurs] / A. Ju. Ardal'janova, P.V. Bizjukov, R.G. Braslavskij i dr. // Otv. red. V.V. Markin, M.F. Chernysh [In V.V. Markin, M.F. Chernysh (eds.); predisl. ak. M.K. Gorshkov. - Moscow: FNISC RAN, 2019. — 545 p. — DOI: 10.19181/ monogr.978-5-89697-323-2.2019._URL: https:// www.isras.ru/index.php?page_id $=1198 \& \mathrm{id}=7751$.

17. Markin K. $V$. Mezhdu veroj i neveriem: nepraktikujushhie pravoslavnye $\mathrm{v}$ kontekste rossijskoj sociologii religii [Between faith and unbelief: non-practicing Orthodox in the context of the Russian sociology of religion] // Monitoring obshhestvennogo mnenija: Jekonomicheskie i social'nye peremeny [Monitoring of public opinion: Economic and social changes]. — 2018. №2. - Pp. 266-282. - DOI: 10.14515/monitoring.2018.2.16.

18. Maslo R.E. Opredelenie ponjatija «Malyj gorod»v global'noj sisteme mirohozjajstvennyh svjazej [Definition of the concept of «Small city» in the global system of world economic relations] // Biznes Inform. — 2014. — №10. Pp. 14-17.

19. Rjazancev I.P., Pisarevskij V.G. Filosofija rannego hristianstva i vyzovy cifrovizacii. Mezhdunarodnaja konferencija «Filosofija rannego hristianstva $\mathrm{V}$ jepohu cifrovizacii», Katolicheskij universitet Fuzhjen' (Tajvan', 6-7 dekabrja 2019 g.) [The philosophy of early Christianity and the challenges of digitalization. International Conference «Philosophy of Early Christianity in the Era of Digitalization», Fuzhen Catholic University (Taiwan, December 6-7, 2019)] // Zhurnal «Jekonomicheskaja sociologija». - 2020. — Vol. 21. - №2. - Pp. 91-98.

20. Uzlaner D.A. Sekuljarizacija kak sociologicheskoe ponjatie [Secularization as a sociological concept] // Sociologicheskie issledovanija [Sociological research]. — 2008. — №8.

21. Filatov S. B., Lunkin R. N. Statistika rossijskoj religioznosti: magija cifr i neodnoznachnaja real'nost' [Statistics of Russian religiosity: the magic of numbers and ambiguous reality] // Sociologicheskie issledovanija [Sociological research]. — 2005. — №6.

22. Harisson L. Evrei, konfuciancy i protestanty: kul'turnyj kapital i konec mul'tikul'turalizma [Jews, Confucians and Protestants: cultural capital and the end of multiculturalism] [Jelektronnyj resurs] // Doklad na mezhdunarodnoj konferencii NIU VShJe. - 2009. — URL: https://www.hse.ru/ news/science/7075536.html (Date accessed: 10.05.2020).

23. Chesnokova V.F. Tesnym putem. Process vocerkovlenija naselenija Rossii $\mathrm{v}$ konce XX veka [In a close way. The process of the Church formation of the population of Russia at the end of the XX century]. - Moscow, 2005. - 304 p.

24. Shabaev Ju. P., ZherebcovI.L., Zhuravlev P.S. «Russkij Sever»: kul'turnye granicy i kul'turnye smysly [«Russian North»: cultural boundaries and cultural meanings]// Mir Rossii [World of Russia]. — 2012. №4. - Pp. 134-153.

25. Jasin E. G. Modernizacija rossijskoj jekonomiki: chto v povestke dnja [Modernization of the Russian economy: what is on the agenda] // Jekonomicheskij zhurnal Vysshej shkoly jekonomiki [Economic Journal of the Higher School of Economics]. - 2001. - Vol. 5. №2. - Pp. 158-178.

26. Jasin E., Jakovlev A. Konkurentosposobnost' i modernizacija rossijskoj jekonomiki [Competitiveness and modernization of the Russian economy] // Voprosy jekonomiki [Economic issues]. - 2004. — №7. - Pp. 4-34.

27. Guimarães M., Nunes. L., Barreira A., Panagopoulos $T$. What makes people stay in or leave shrinking cities? An empirical study from Portugal // European Planning Studies. 2016. - Vol. 24. - №9. - Pp. 1684-1708. DOI: $10.1080 / 09654313.2016 .1177492$.

28. Harvey D. Spaces of hope. - Edinburgh University Press, Edinburgh, 2000. - 310 p.

29. Lebedev S., Blagoevic M., Pokaninova $E$. Value- and Reflection-based Approach to Indicators of Orthodox Religiosity of the Population [Electronic resource] // Stanovništvo. (In Serbian). - 2020. — №58 (1). — Pp. 47-61. URL: http://idn.org.rs/ojs3/stanovnistvo/index. $\mathrm{php} / \mathrm{STNV} /$ article/view/381 (Date accessed: 08.08.2020).

30. Negroponte N. Being Digital. - NY: Knopf, 1995. - $256 \mathrm{p}$.

31. Pollak D. Renaissance des Religiösen? Veränderungen auf dem religiösen Feld in ausgewählten Ländern Ost- und Ostmitteleuro- 
pas // Archiv für Sozialgeschichte. — 2011. №51. - P. 116.

32. Ryan B.D. Design after Decline: How America Rebuilds its Shrinking Cities. - Philadelphia: University of Pennsylvania Press, 2012. - $288 \mathrm{p}$.

33. Sassen S. The global city: New York, London, Tokyo [Electronic resource]. - Princeton University Press, Princeton, NJ, 2001. — URL: http://dx.doi.org/10.1515/9781400847488.

34. Scott A., Storper M. Regions, globalization, development // Regional Studies. 2007. 一 №37 (6-7). — Pp. 579-593. - DOI: 10.1080/0034340032000108697a.

35. Skinner C. Digital human. The fourth revolution of humanity includes everyone. Marshall Cavendish International (Asia) Pte Ltd, 2018. - $328 \mathrm{p}$.
36. Tapscott D. The Digital Economy: Promise and Peril In The Age of Networked Intelligence. - NY: McGraw-Hill,1994. — 368 p.

37. Van den Berg L., Drewett R., Klaasen L. Urban Europe: A Study of Growth and Decline. - Pergamon, Oxford, 1982. - 162 p.

38. Weill P., Woerner $S$. Digital business transformation. - Harvard Business Review Press (USA), 2018. - 260 p.

39. Issledovanie povedencheskih i institucional'nyh predposylok tehnologicheskogo razvitija regionov RF [Research of behavioral and institutional prerequisites for the technological development of the regions of the Russian Federation] [Jelektronnyj resurs]. — URL: https:// www.rvc.ru/upload/iblock/0e8/attitudes_to technologies_and_innovations_in_Russiapdf (Date accessed: 09.02.2021).

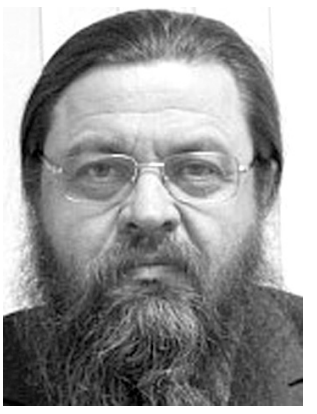

Рязанцев Игорь Павлович - доктор экономических наук, профессор, заведующий кафедрой социальных наук историкофилологического факультета Православного Свято-Тихоновского гуманитарного университета.

Ryazantsev Igor Pavlovich - Doctor of Economic Sciences, Professor, Head of the Department of Social Sciences, Faculty of History and Philology, St. Tikhon's Orthodox University.

115184, г. Москва, ул. Новокузнецкая, 236

23b Novokuznetskaya st., 115184, Moscow, Russia E-mail: dekan-soc@mail.ru 


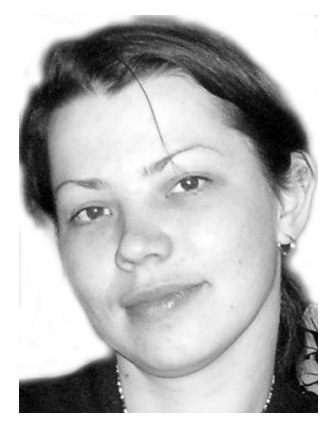

Подлесная Мария Александровна - кандидат социологических наук, старший научный сотрудник Института социологии Федерального научно-исследовательского социологического центра Российской академии наук.

Podlesnaya Maria Alexandrovna - Candidate of Sociological Sciences, Senior Researcher, Institute of Socilogy of the Federal Research Sociological Center of the Russian Academy of Sciences.

117218 , г. Москва, ул. Кржижановского, 24/35, к. 5 24/35 Krzhizhanovskogo st., bld. 5, 117218, Moscow, Russia E-mail: yamap@yandex.ru

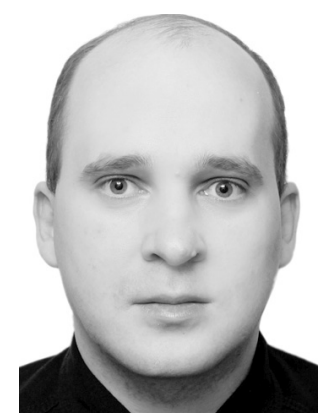

Писаревский Василий Геннадьевич - кандидат социологических наук, доцент Православного Свято-Тихоновского гуманитарного университета.

Pisarevsky Vasily Gennadievich - Candidate of Sociological Sciences, Assistant Professor of St. Tikhon's Orthodox University.

115184, г. Москва, ул. Новокузнецкая, 236 23b Novokuznetskaya st., 115184, Moscow, Russia E-mail: wausily@yandex.ru

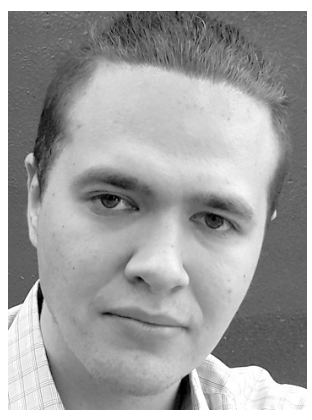

Рязанцев Вадим Игоревич - магистр Московского государственного университета имени М.В. Ломоносова.

Ryazantsev Vadim Igorevich - Master of Science of Moscow State University.

119234, г. Москва, Ленинские Горы мкр., 1, корп. 3, стр. 33 1 Leninskie Gory microdistrict, bld. 3, str. 33, 119234, Moscow, Russia. E-mail: vir220497@gmail.com 